\title{
CHANGING THE CONSTITUTION: How Nationalist Parties in Regional Government are bringing Change to the UK Constitution
}

\author{
by Malcolm Harvey
}

School of History and Politics, University of Stirling, United Kingdom

Email: malcolmharvey1984@googlemail.com

\begin{abstract}
This paper will examine the dynamics of devolution in the United Kingdom since the 2007 elections to the Scottish Parliament and National Assembly for Wales which resulted in the Scottish National Party and Plaid Cymru entering government for the first time in their history. It will analyse the impact that their participation in governance at this level has had upon their stated goals of constitutional change. In particular it will examine the methods employed by these parties in order to advance these constitutional goals - specifically the role of consultation and referendum in creating the pressure for change. It will argue that both have been key drivers for constitutional change and have created what has become a critical mass regarding the constitutional debate in the UK.
\end{abstract}

Keywords: constitutional change, parties, Wales, Scotland are bringing change to the UK Constitution", Federal Governance, vol. 8 no. 1, pp. 2-16. 


\section{About Federal Governance}

Federal Governance is an online graduate journal on theory and politics of federalism and multilevel governance. Its mandate is to engage the global federalism community and reach out to outstanding graduate students interested in federalism and multi-level governance. By providing a platform for graduate students to have early success in their careers, Federal Governance seeks to promote and sustain interest in federalism and multi-level governance research among graduate students. Allied with the Forum of Federations and founding partner, Institute of Intergovernmental Relations at Queen's University; Federal Governance aims to contribute to a global dialogue on federalism.

Co Chairs, Advisory Committee:

Rupak Chattopadhyay and Christian Leuprecht

Publisher:

Forum of Federations

Managing Editor:

Annegret Eppler

Associate Editors:

Joshua Cerovski, Dominic Heinz,

Eva-Maria Maggi and Victoria Tait

\section{Terms of Use}

Your use of this Federal Governance article indicates your acceptance of Federal Governance's Terms and Conditions of Use, available at www.federalgovernance.ca/terms. Federal Governance's Terms and Conditions of Use provides that you may use Federal Governance content only for personal, academic and non-commercial use. Each copy of any part of this Federal Governance article must contain the same copyright notice that appears on the screen or printed page of such transmission. 


\section{Introduction}

When Labour delivered devolution in the United Kingdom after referendums in 1997, they did so knowing, in Ron Davies oft-quoted words, that devolution would be 'a process, not an event" (Davies, 1999). They also did so from a position of strength in the "Celtic fringe", winning a "plurality of the Welsh vote at every UK General Election" since 1922 (Scully and Elias, 2008: 103n) and becoming the dominant party in Scottish politics in 1964 (Blondel, 1968; Hutchison, 2001). They had no expectation then, that by 2007 that nationalist parties in both the Scottish Parliament and the National Assembly for Wales (NAW) would emerge in government. Indeed, with Labour's worst performance in a Wales-wide election since 1918 (Scully and Elias, 2008: 106) and Scottish Labour's failure to win a plurality of votes and seats in Scotland for the first time since 1955 (Jones, 2008: 24), this was a historic change in devolved politics. The Scottish National Party (SNP) explored coalition options which quickly evaporated and, while they managed to obtain a minor agreement with the Scottish Green Party, they decided to govern as a minority. In Wales, however, coalition discussions were ongoing for a period of two months after the election, with several options on the table - a Labour minority administration (though with only 26 of the 60 seats in the NAW, this was never a feasible long-term option), a Labour-Liberal Democrat coalition (which had existed previously), a so-called rainbow coalition of Plaid Cymru-Conservatives-Liberal Democrats (which was touted heavily, only to fall on Liberal Democrat support) and the final outcome, a Labour-Plaid Cymru coalition (McAllister and Cole, 2007: 543).

Thus, the 2007 devolved elections ended with two parties in government whose desire to change the constitution of the United Kingdom was clear from their manifestos. The SNP had promised the

"Publication of a White Paper detailing the concept of Scottish independence in the modern world as part of preparations for offering Scots the opportunity to decide on independence in a referendum, with a likely date of 2010."

(SNP, 2007: 8)

Plaid Cymru's manifesto called for

"A referendum during the next Assembly term to establish a Proper Parliament for Wales, on the model set out in the Government of Wales Act, 2006."

(Plaid Cymru, 2007: 36)

This commitment was carried into government through the One Wales Agreement with the Welsh Labour Party, which committed both parties to use the provisions of the Government of Wales Act "to the full" and "to proceed to a successful outcome of a referendum." In order to do so, the coalition would "set up an all-Wales Convention" to 
engage the public in discussions about devolution and extending the powers of the NAW (Labour/ Plaid Cymru, 2007: 6).

This paper will examine these combined strategies towards affecting constitutional change in detail, arguing that using means of public engagement - consultation and referendum - parties who have campaigned for an extension of powers for the devolved institutions have sought to establish further legitimacy and credibility for their demands. In each case, a lengthy consultation process has opened the debate up to public scrutiny and engagement as a precursor to a national plebiscite on the issue of the respective constitutional goals. In Scotland, the SNP's ambition was to have a referendum solely on independence, with an affirmative vote providing the Scottish Government the legitimacy to open negotiations with Westminster over a settlement resulting in Scottish independence (Scottish Government, 2007: 35). As the 2007-11 parliamentary session moved on, it became clear that a single-option referendum was a non-starter with the opposition parties, and thus a multi-option paper with independence, enhanced devolution (later known as "devo-max") and the status quo as options, became the argument. However, in the later part of the term, First Minister Alex Salmond recognised even that concession lacked the support of the other parties in the Scottish Parliament, and the referendum bill was postponed further in the hope that the SNP were in a position to introduce a similar bill in the next parliamentary term. In Wales, Plaid's ambition was less controversial: to activate the clause in the Government of Wales Act 2006 which would trigger a referendum, with a positive outcome leading to the block devolution of legislative powers to the NAW in fields set out the Act itself (Government of Wales Act, 2006: 111 [section 94]). In the latter case, Plaid's goal of extending the power of the NAW was shared by each of the parties represented in Cardiff Bay while in the Scottish case, opinion on constitutional change is much more varied, with each party taking a distinct position along a centralistdecentralist axis. One thing that is clear is that in both cases, the "debate is no longer about whether change is needed, it is about what form that change should take' (Crawford, 2010: 95).

\section{A National Conversation}

The SNP held to their manifesto commitment and produced a White Paper entitled Choosing Scotland's Future - A National Conversation in August 2007, only three months after taking office. The White Paper itself set out what the Scottish Government viewed as three "realistic choices" for the future of Scotland. These were: maintaining the status quo of a Scottish Parliament within the United Kingdom, redesigning devolution to extend the powers of the Scottish Parliament (including fiscal powers but short of independence) and the Scottish Government's preferred option, independence. (Scottish Government, 2007: vii-viii). The Scottish Government went to great lengths within this document to show that this was not to be a one-way street, that all views, even - and perhaps, in particular - those which were opposed to 
independence, were welcomed within the discussion (Jones, 2008: 51; Mitchell, 2008: 254). Chapter 2 of the White Paper saw the Scottish Government propose several changes to the constitutional arrangements, proposals that would strengthen devolution (Lynch, 2009, 12-13), including the devolution of powers in the field of taxation, energy policy, firearms legislation, employment law and broadcasting (Scottish Government, 2007: 11-17). These proposals were pragmatic in their approach. The party recognised that their own constitutional preference independence - was not the constitutional preference of the majority in the Scottish Parliament (and, indeed, according to opinion polls, only a minority of the Scottish population) (TNS System Three/ Sunday Herald cited Curtice, 2009: 16-17). Thus, by presenting their own, more radical, goal alongside proposals which would provide the Scottish Parliament with more powers, the SNP Scottish Government have been able to promote their second preference - a considerable extension of powers for the Scottish Parliament - as a more reasoned, less radical proposal.

To engage the public with the constitutional debate, the party launched $A$ National Conversation, a three-year long consultation designed as a precursor to the planned introduction of a referendum bill to the Scottish Parliament, which was scheduled for autumn 2009, followed by a referendum the following year. The consultation was split into three organic phases. The first phase was launched by First Minister Alex Salmond at Napier University on $14^{\text {th }}$ August 2007 to coincide with the launch of Choosing Scotland's Future. For the following six months, the consultation process was predominantly limited to an online debate, with articles by Cabinet members and comments, letters and emails from the public, while Alex Salmond delivered several public lectures to maintain public interest in the consultation (Keating, 2009: 6). Seven months later, phase two of the process was launched, and was distinctly more public oriented, comprising meetings with businesses, trades unions and churches, as well as Cabinet 'roadshow' events around the country (in the summer of both 2008 and 2009) and 29 public question and answer sessions. These events provided mixed success for the SNP, with detailed evidence suggesting the events were well attended and that the public were engaged in discussions, but that the constitutional debate was a minority concern amongst those who attended (Harvey and Lynch, 2010: 10).

Finally, phase three of $A$ National Conversation marked the end of the original consultation and was intended as the beginning of a referendum campaign. That the referendum campaign itself never materialised is dealt with below. Nevertheless, the consultation had played a significant role in furthering the constitutional debate in Scotland, spawning as it did the Unionist parties' collective response, the Commission on Scottish Devolution (chaired by Sir Kenneth Calman). While the Calman Commission's remit was narrower (it specifically omitted independence from its considerations) and its recommendations weaker (minor additions to powers already devolved, formalisation of intergovernmental relations and a small step towards fiscal autonomy) than the Scottish Government would have liked, it nevertheless provided 
evidence that the SNP have succeeded in moving the constitutional debate forward and, crucially for them, that the other parties began to move in the direction of accepting more devolution (Harvey, 2010: 18).

\section{The All-Wales Convention}

In contrast with the SNP's position as a minority government, Plaid Cymru's experience of government as the junior partner in coalition with Labour in the NAW has provided much more in the way of consensus with regards the constitutional debate. Equally, the fact that devolution in Wales has already been altered - and provision made for further devolution - through the Government of Wales Act 2006, has meant that political discussion in Wales has already centred on extending devolution. In this respect, the coalition agreement between Labour and Plaid - the One Wales Agreement - simply codified a pre-existing consensus within the NAW on the need for further (legislative) devolution. Nevertheless, the coalition was an important watershed moment in post-devolution Welsh politics, an 'unprecedented' agreement between Labour and the nationalists (Scully and Elias, 2008: 107) which was 'ground-breaking' in its linking two parties which had historically been rivals (McAllister and Cole, 2008: 543).

The One Wales Agreement set in formal terms the conditions each party would have to sustain for the coalition to continue, with the All-Wales Convention a key component of Plaid's support for the agreement. The All-Wales Convention had a wide remit, to provide information on how the NAW currently operates, to debate the extension of its powers and to report to the Welsh Assembly Government its findings at the end of the consultation period (All-Wales Convention, 2009). The process consisted of public meetings around Wales as well as written submissions of evidence to the committee. In all, 2,700 submissions (All-Wales Convention, 2009) were made, from a variety of sources, before the final report of the committee was prepared and presented to the Welsh Assembly Government in November 2009. The All-Wales Convention, chaired by former UN diplomat Sir Emyr Jones Parry, began work as an Executive in March 2008 tasked with several aims. The first of these was an informative role - educating the Welsh public about the role of the NAW and the powers which it currently had available, raising awareness of the devolution settlement, how it works and the potential impact any change in the powers of the NAW would have on the general population. Its second role was to stimulate discussion on the issue of expanding devolution, opening a consultation with the Welsh population on the issue of full lawmaking powers. Finally, the Convention was tasked with analysing the views of the public, assessing the mood with regards increased powers and make a recommendation to the Welsh Assembly Government on the issue of holding a referendum (All-Wales Convention Establishing Committee Report, 2008: xx). 
In order to fulfil the informative role, the Convention organised over sixty events across Wales (All-Wales Convention, 2009). These ranged from formal meetings between Sir Emyr Jones Parry and County Councils across Wales and evidence gathering sessions at Welsh institutions - schools, universities and businesses - to more public events, including question and answer sessions with the Executive Committee. The voluntary sector played a role in the debate while some of the more unique consultation events included a curry night at a Labour Club in Port Talbot and events in shopping centres in Bridgend and Caerphilly. Events were extended to universities, "Question Time" styled events, rugby clubs, formal evidence-gathering sessions, even the Royal Welsh Show hosted members of the Executive Committee. In addition, the All-Wales Convention website provided visitors the opportunity to contribute their views to the discussion and established a page on the social-networking site Facebook which generated a lively online discussion.

In total, the Executive Committee hosted 23 public events, conversing with over 1700 people, while 13 formal evidence gathering sessions saw evidence provided by 76 individuals and organisations. 608 organisations from within Wales provided written evidence to the AWC and 1,925 individuals completed questionnaires (All-Wales Convention, 2009: 13). Thus, contributions to the All-Wales Convention came from a variety of sources, through several different types of event held around the country, in different forums and through different mediums, all with the dual purpose of increasing the understanding of Welsh devolution examining attitudes towards extending the powers of the NAW.

In its final report, the All-Wales Convention found that the current process, whereby Measure-making powers can be transferred to the NAW through Legislative Competence Orders - that is, the process set out in Part 3 of the Government of Wales Act 2006 - should be abandoned in favour of the instant transfer of legislative powers in the twenty Fields as set out in Part 4. Part 4, according to the All-Wales Convention, offers a "substantial advantage" over the current process in several ways. It would allow the process of devolving power to become much more efficient; provide a strategic approach in drafting legislation; offer greater clarity in the system which had previously been lacking and more consistency with the democratic tradition (All-Wales Convention, 2009: 98). On that basis, the All-Wales Convention recommended a referendum in accordance with the stipulation in the Government of Wales Act 2006 that legislative powers could be transferred in bulk on the acceptance of those plans by a majority of the Welsh public.

\section{The Welsh Powers Referendum 2011}

The Government of Wales Act 2006 was categorised in some quarters as a 'revolution' in Welsh devolution but one which gave something to both proponents and opponents of devolution (Navarro and Lambert, 2007: 18-19). It was a compromise of views 
within the Labour Party - it delivered more in the way of legislative powers for the NAW for devolution supporters but put a number of mechanisms in the way of their transfer, enough to satisfy opponents that power would not be transferred overnight (Trench, 2007: 33). These mechanisms were set out in detail in Part 3 and Part 4 of the Act, with Part 3 indicating that the Assembly could request the transfer of powers one at a time through a complex procedure involving Legislative Competence Orders. Alternatively, Part 4 made provision for the transfer of powers in all twenty fields conditional upon the return of an affirmative vote in a referendum - a referendum which could only be called with the agreement of two-thirds of the NAW, the Secretary of State for Wales and both Houses of the UK Parliament. It was, to many, an 'elegant and ingenious' development (Wyn Jones and Scully, 2008: 64). It allowed those in favour - Plaid and pro-devolutionist parts of Labour and the Liberal Democrats and, indeed, Welsh Conservatives - to see devolution moving forward, an opportunity to improve the NAW with enhanced powers, while for those opposed the conditions imposed upon the transfer of power meant they could still make the argument against further powers in a referendum campaign.

While Plaid campaigned for a referendum in the 2007 Welsh Assembly election - and made it a key plank of the coalition's One Wales Agreement - then Secretary of State for Wales, Labour's Peter Hain was not as keen to move to a referendum quickly. He was adamant that a referendum should not be rushed but that he would support a 'Yes' vote "when we are confident we can win" (Hain, 2009a, 2009b). Nevertheless, the NAW voted unanimously (53 in favour to zero against) on 9 February 2010 to start the parliamentary process toward the referendum. ${ }^{1}$ Naturally, the consensus - and unanimity of the vote - was not a reflection of the influence of Plaid in the constitutional debate, but the fact that, in a little under the four years since the Government of Wales Act 2006 was passed (and three since its terms were implemented) a consensus of opinion in the NAW was formed on holding an early referendum was testament to their making the issue a key plank of their support for coalition with Labour. With a new Conservative-led government at Westminster, there was a concern that the referendum would be blocked or, at the very least, postponed. However, incoming Conservative Secretary of State for Wales Cheryl Gillan moved quickly to quell those fears, indicating that the referendum was 'a priority' and that it would be scheduled 'in the first quarter of 2011' (Gillan, 2010). Thus, a referendum that the pilot of the Government of Wales Act 2006 did not consider to be imminent (Hain, 2009a) was held in March 2011. It delivered a resounding yes vote, with $63 \%$ in favour on a turnout of $35 \%$. The 220,392 vote margin was a considerable increase on the margin of just 6,721 in the 1997 referendum held to establish the NAW (REF). The result has led to the third radical

1 The Record of Proceedings in the National Assembly for Wales for Tuesday, 9 February 2010, available to view at http://www.assemblywales.org/bus-home/bus-chamber/buschamber-third-assembly-rop.htm?act=dis\&id=166346\&ds=2/2010\#6 (last access June 6, 2011) 
change to what is effectively a new Welsh constitution since devolution in 1999: what has been described as "National Assembly Mark I" (from 1999-2007, the "body corporate' elected-administrative devolution model); "National Assembly Mark II" (from 2007-2011, the quasi-legislative devolution model, remaining dependent upon Westminster for transfer of powers); and a new, post-referendum "Mark III", a legislative National Assembly for Wales with full competence in the twenty Fields set out in the Government of Wales Act 2006 (Trench, 2010: 118n). This final change from Mark II to Mark III has been the result of bottom-up regional pressure, pressure which Plaid Cymru influenced from the 2007 NAW election and beyond into the One Wales Agreement.

\section{The (lack of a) Scottish Referendum}

The same, perhaps, cannot be said of the SNP, at least during the 2007-2011 Scottish Parliamentary session. While they delivered on the first half of their manifesto commitment by publishing a White Paper on independence, they could not deliver a referendum on the issue itself, spending three and a half years building up to it before deciding not to bring forward a bill to the Scottish Parliament. A referendum on independence was the key aspect of the SNP's governing platform - and one which was the very least their activists had come to expect from the party's time in government. However, while the party engaged in A National Conversation as a huge (the largest ever conducted by a Scottish Government ${ }^{2}$ ) consultation exercise (the primary objective of which was to lay the groundwork for a referendum to be held during the four-year parliamentary term) no referendum bill was brought forward to the Scottish Parliament (Harvey, 2010: 6). In the first instance, the party was due to lay a referendum bill in the Scottish Parliament in November 2009, immediately after the publication of the second White Paper, Your Scotland, Your Voice. However, with the bill ready to be heard before an SNP-chaired ad-hoc committee, Labour engineered an opportunity to chair the committee (Harvey and Lynch, 2010: 8). A quick re-think on the SNP's part led to the referendum bill being published as a consultation paper instead (Scottish Government, 2010). This had the dual-effect of keeping the issue of a referendum alive through the UK General Election in 2010 and maintaining the element of public participation in the process, an element that had been crucial to the perceived success of $A$ National Conversation. During this period, the SNP courted the Liberal Democrats with a multi-option referendum, with further powers relating to fiscal autonomy (similar to the recommendations of their Steel Commission Report in 2006) but the party stayed the course with the Calman Commission, and were duly rewarded with the opportunity to implement its recommendations through coalition government at Westminster. Publishing the bill as a consultation paper also had the effect of delaying the opportunity to lay the referendum bill in the Scottish Parliament. That delay

2 Interview with Bruce Crawford, SNP MSP and Minister for Parliamentary Business in the Scottish Government, May 2010. 
became a permanent postponement in September 2010 with the news that the SNP Scottish Government had decided not to bring forward a referendum bill before the election in May 2011, citing the lack of opposition support for the bill and the inevitability that they would vote down the bill (The Scotsman, 6 September 2010). This was the reality of minority government for the SNP - the necessity of relying upon the support of other parties to produce a legislative majority.

However, despite the lack of a referendum, the SNP have affected change with regards the constitutional debate in Scotland. Prior to the party's arrival in office in 2007, the sub-total of the Unionist parties engagement with enhancing the powers of the Scottish Parliament was a little-read Liberal Democrat report entitled Moving to Federalism: $A$ New Settlement for Scotland (The Steel Commission, 2006). With the Scottish Government's National Conversation dominating the constitutional debate, the Unionist parties realised that they had to do something to wrest the constitutional initiative back from the nationalists. The establishment of the Commission on Scottish Devolution (detailed above) was their response, and though it never engaged with the Scottish Government's constitutional debate, resulting in something of a "disjointed constitutional debate" (Trench, 2008: 14-15), the final recommendations of the Commission represented a distinct change in policy for the Unionists. The three parties (Labour, the Conservatives and the Liberal Democrats) now found themselves supporting an increase (albeit, a minor one) in the powers of the Scottish Parliament. And, indeed, these powers appear ready to be devolved, with the Conservative-Liberal Democrat UK Government currently legislating to implement the Calman recommendations in a new Scotland Bill. Although the Calman recommendations do not go far enough for the SNP - indeed, they were described in interviews with the author $^{3}$ as "feeble, but welcome progress" and a "spoiling tactic for independence" they nevertheless provide evidence that the SNP has influenced constitutional change in the UK in the direction of further powers for the Scottish Parliament.

\section{2011 Regional Elections}

The elections to the Scottish Parliament and the National Assembly for Wales in May 2011 brought mixed fortunes for the respective nationalist parties. In Wales, after Plaid had successfully campaigned to hold a referendum to extend the powers of the NAW a campaign which ended with a positive outcome in the referendum itself - the party found itself have a disappointing night, losing three seats and seeing the Welsh Conservatives overtake them in terms of Assembly Members. More pressingly, the party lost its position as a junior coalition partner in the Welsh Assembly Government as Labour returned exactly half of the 60 seats in the Senedd and intended to govern

3 Interviews with Alasdair Allan, SNP MSP for the Western Isles (23 March 2010) and Keith Brown, SNP MSP for Ochil, Minister for Schools and Skills in the Scottish Government (16 April 2010). 
as a minority. In Scotland, the contrast could not have been greater. The SNP won a stunning victory, capturing 53 of the 73 Scottish Parliamentary constituencies and an outright majority in Holyrood with a total of 69 of the 129 seats. The outright majority was all the more remarkable given the additional member electoral system was to designed to prevent any party from winning a majority of seats in the Scottish Parliament. What this means for the constitutional debate is clear - the SNP now have a mandate to introduce and pass an independence referendum bill, with a likely date of 2014 for such a vote.

\section{Conclusion}

The unwritten constitution of the United Kingdom underwent radical change in 1999 as the country moved from a centralised political system to a partly decentralised system of asymmetrical devolution. While the UK Parliament has, until very recently, resisted pressure for change to the devolved settlement for Scotland, the Welsh case has proved much more volatile (Trench, 2010: 118). Almost from the start there was pressure for change from the Presiding Officer of the NAW Dafydd Elis Thomas, himself a Plaid Cymru Assembly Member. He, and others, felt the system of elected administrative devolution and the 'body corporate' model to be ineffective and within the first term created a de facto separation of executive and administrative functions (Trench, 2010: 123). This separation, along with changes to the electoral arrangements, increasing the number of members of and bestowing of legislative powers upon the NAW, was also recommended by the Richard Commission, adding to the pressure for change (Richard Commission, 2004). Those pressures forced the then-Labour UK Government into accepting the need for change, culminating in the Government of Wales Act 2006, with its provisions for incremental legislative devolution in specific policy areas by request and the immediate transfer of powers in all twenty Fields in the event of an affirmative referendum result. Thus the mechanism for further legislative devolution was created, and further pressure as a result of the One Wales Agreement - as well as the Report of the All-Wales Convention - led to the scheduling of a referendum for early 2011 , clear evidence of the bottom-up pressure from the regional level influencing potential constitutional change in the Welsh case.

While the case in Scotland is not as clear cut - with a relatively stable devolution settlement delivered in 1999, the Unionist parties have seen little need to alter the legislation - there is also evidence that bottom-up pressures from the Scottish Parliament have influenced constitutional change. When the SNP won power in 2007 and embarked upon their National Conversation consultation on the constitutional future of Scotland, they forced a response from the Unionist parties - a Commission on Scottish Devolution, tasked to report on the formative years of the devolution project and to recommend improvements. Recommendations they did make, and the subsequent UK government is currently in the process of legislating upon them. By 
arguing for (and creating a constitutional debate centred upon) independence, the SNP have engaged the other parties in Scotland on their constitutional goal, pressuring them into adopting a position of favouring more powers short of independence and creating a critical mass around this position. In this respect, the SNP have provided the pressure that led to bottom-up calls for an extension to the devolved powers of the Scottish Parliament. In both cases the catalyst for change has been the election of nationalist parties into the regional tier of government and the influence they have been able to project from this position. From here, both Plaid Cymru and the SNP have been afforded the opportunity to engage the public (and, at length, the Unionist parties) in the constitutional debate through consultation processes. In the Welsh case that has led to a post-legislative referendum to imbue the NAW with further legislative powers (a referendum which was already on the statute books, the timing of which was open to influence) while in Scotland the election of a majority SNP government means that a referendum on independence in the present Scottish Parliamentary term appears a certainty, while the position of influence the party now finds itself in may lead to further powers being devolved through the Scotland Bill. The UK constitution is under pressure, and while Wales may have travelled this far and no further for the time being, the SNP's stunning electoral victory means that further devolution to the Scottish Parliament is now inevitable - and end of the Union is a real possibility. 


\section{References}

[1] All-Wales Convention 2009, Report of the All Wales Convention Cardiff: National Assembly for Wales.

[2] All-Wales Convention 2008, Report of the Establishing Committee of the All-Wales Convention Cardiff: National Assembly for Wales.

[3] Blondel, J. 1968, "Party Systems and Patterns of Government in Western Democracies", Canadian Journal of Political Science, vol. 1, no. 2, pp. 180-203.

[4] Crawford, B. 2010, "Ten Years of Devolution", Parliamentary Affairs, vol. 63, no. 1, pp. 89-97.

[5] Curtice, J. 2009, "Public Attitudes and Elections", in Scotland: Devolution Monitoring Report, ed. P. Cairney, UCL, London: The Constitution Unit.

[6] Davies, R. 1999, "Devolution: A Process not an Event", The Gregynog Papers, vol. 2, no. 2, Cardiff: Institute of Welsh Affairs.

[7] Gillan, C. 2010, Untitled Speech, Address to the National Assembly for Wales on the Queen's Speech, 16 June 2010.

[8] Government of Wales Act 2006, London: HMSO.

[9] Hain, P. 2009b, Untitled Speech, Address to the National Assembly for Wales on the Queen's Speech, 25 November 2009.

[10] Hain, P. 2009a, "Good News: Comprehensive Law-Making Powers for Wales", Speech delivered at Cardiff University, 29 October 2009.

[11] Harvey, M. 2010, "A chat's a chat for a' that: the SNP's National Conversation as the Constitutional Policy of a Nationalist Party in Government", paper Presented to the European Consortium for Political Research Summer School on Federalism, Regionalism and Public Policy, Edinburgh, August 2010.

[12] Harvey, M. and Lynch, P. 2010, "From National Conversation to Independence Referendum?: The SNP Government and the Politics of Independence", paper Presented to Political Studies Association Conference, Edinburgh, March-April 2010.

[13] Hutchison, I. G. C. 2001, Scottish Politics in the Twenty-First Century, Basingstoke: Palgrave.

[14] Jones, P. 2008, "Scotland: The Nationalist Phoenix" in The State of the Nations 2008, ed. A. Trench, Exeter: Imprint Academic.

[15] Keating, M. 2009, "The Scottish Constitutional Debate" in Scotland: Devolution Monitoring Report, ed. P. Cairney, UCL, London: The Constitution Unit.

[16] Labour/ Plaid Cymru 2007, One Wales: A progressive agenda for the government of Wales - An agreement between the Labour and Plaid Cymru Groups in the National Assembly, Cardiff: Welsh Labour Party/ Plaid Cymru.

[17] Lynch, P. 2009, Regionalist Parties, Economic Development and Regional Government: The SNP in Government 2007-2009, IXth Congreso Asociación 
Harvey, Changing the Constitution

13

Española de Ciencia Política y de la Administración (AECPA) Conference Paper, Malaga, September 2009.

[18] McAllister, L. and Cole, M. 2007, "Pioneering New Politics or Re-arranging the Deckchairs? The 2007 National Assembly for Wales Election and Results" in The Political Quarterly, vol. 78 no. 4, pp. 536-546.

[19] Mitchell, J. 2008, "Ever Looser Union' in The State of the Nations 2008, ed. A. Trench, Exeter: Imprint Academic.

[20] Navarro, M. and Lambert, D. 2007, "Some Effects of the Government of Wales Act 2006", Contemporary Wales, vol. 20, no. 1, pp. 13-30.

[21] Plaid Cyrmu 2007, Make a Difference! Plaid Cymru's 2007 Election Manifesto, Cardiff: Plaid Cymru.

[22] Richard Commission 2004, Report of the Richard Commission: Commission on the Powers and Electoral Arrangements of the National Assembly for Wales Cardiff: National Assembly for Wales.

[23] Scottish Government 2010, Scotland's Future: Draft Referendum (Scotland) Bill Consultation Paper, Edinburgh: Scottish Government.

[24] Scottish Government 2007, Choosing Scotland's Future: A National Conversation - Independence and Responsibility in the Modern World, Edinburgh: Scottish Government.

[25] [Scottish National Party 2007, It's Time, Edinburgh: SNP.

[26] Scully, R. and Elias, A. 2008, “The 2007 Welsh Assembly Election' Regional and Federal Studies, vol. 18, no. 1, pp. 103-109.

[27] The Steel Commission 2006, Moving to Federalism: A New Settlement for Scotland, Edinburgh: Scottish Liberal Democrats.

[28] Trench, A. 2010, "Wales and the Westminster Model", Parliamentary Affairs, vol. 63 no. 1 , pp. 117-133.

[29] Trench, A. 2007, "Old Wine in New Bottles? Relations between London and Cardiff after the Government of Wales Act 2006", Contemporary Wales, vol. 20, no. 1, pp. 31-50.

[30] Whittaker, A. 2010, "SNP to shelve plans for vote on independence", The Scotsman, 6 September 2010, available at: http://thescotsman.scotsman.com/news/SNP-to-shelve-plans-for.6514143.jp (accessed 7 September 2010)

[31] Wyn Jones, R. and Scully, R. 2008, "Welsh Devolution: The End of the Beginning and the Beginning of...?" in The State of the Nations 2008, ed. A. Trench, Exeter: Imprint Academic. 